\title{
Underlying Factors on Consumer's Behaviour in Asking for Sales Receipts Towards Tax Collection Maximization: An Application of Theory of Planned Behaviour
}

\author{
Emmanuel Simon Mwang'onda ${ }^{1,}$,, Steven Lee Mwaseba ${ }^{1}$, Amon Frank Nkembo $^{2}$ \\ ${ }^{1}$ Department of Rural Development and Regional Planning, Institute of Rural Development Planning, Dodoma, Tanzania \\ ${ }^{2}$ Institute of Rural Development Planning, Dodoma, Tanzania \\ Email address: \\ Emmer2011@gmail.com(E. S. Mwang'onda),smwaseba@irdp.ac.tz(S. L. Mwaseba), amonnkembo21@gmail.com(A.F. Nkembo) \\ ${ }^{*}$ Corresponding author
}

\section{To cite this article:}

Emmanuel Simon Mwang'onda, Steven Lee Mwaseba, Amon Frank Nkembo. Underlying Factors on Consumer's Behaviour in Asking for Sales Receipts Towards Tax Collection Maximization: An Application of Theory of Planned Behaviour. Psychology and Behavioral Sciences. Vol. 7, No. 1, 2018, pp. 14-20. doi: 10.11648/j.pbs.20180701.14

Received: March 8, 2018; Accepted: March 26, 2018; Published: April 23, 2018

\begin{abstract}
Tax administrations have been working on how to deal with non-compliance behaviour at minimal cost, while maximizing collections without affecting efficiency operations of entities in an economy. Studies have been done to understand complexity of this behaviour from economic, social norms, ethical and psychological perspectives. Using theory of planned behaviour (TPB), this study embarks on the same journey by investigating the behaviour of consumer as third-party tax enforcer through asking for sales receipts after transaction. From data collected at Dodoma Municipality by questioning 118 respondents, the study unveils that, attitude and subjective norms have a positive effect on intention to ask for sales receipt, while; there was no effect of perceive behaviour control on customer's intention to ask for sales receipt. Most of the customers acknowlege goodness, desirability or importance of asking for sales receipt, which is argued to have implication on effeciency of tax collection exercise. Morover relatives and friends have significant effect of individual behaviour of asking for receipt, thus existance of habit of asking for sales receipt among community members reduces moral and ethical cost of acting as a third-party tax enforcer. Efforts should be directed more toward winning consumers' support rather than using more force on traders, and adoption and use of EFDs should go parallel with other strategies aiming at improving tax collection.
\end{abstract}

Keywords: Compliance, Consumer Behaviour, Value-Added Tax

\section{Introduction}

\subsection{Background}

Tax is normally the main source of public revenue in any economy, this revenue is collected from consumptions, income, properties, individuals and corporations. It is complimented by other sources of revenues such as royalty, dividends, grants, domestic borrowing and loan and grants from other countries. Given the tax base, having an effective tax system that fairly distribute the tax burden among economic agents is a big push toward poverty and illiteracy eradication among countries [1]. It was reported that, for developing countries to meet the desired millennium development goals, countries were to raise tax share of GDP to 20 percent [2].

Observations made on OECD countries, shows consumption tax forms major portion of total tax revenue [3]. One of consumption tax is Value-Added Tax (VAT) which is tax revenue source that has gained its popularity in many countries in late twentieth century, and it accounts for about a quarter of all tax revenues collected worldwide. This tax was introduced back in 1920's, but gained recognition in France 1948, then Brazil and Denmark in 1967 [4].

It has become more popular because, it is an easier tax to enforce compared to income tax; also it is levied on commodities at all levels of production, and the pinch of this tax is felt by all of final consumers regardless of their status [5]. Currently the countries with a high percentage of tax share of GDP are Denmark, France, Belgium Finland and 
Italy, whereby the tax-burden ratio is above $40 \%$ [6].

Tanzania being among developing countries with motives to achieve sustainable development goals and attain total economic development, efficient and effective revenue collection is of great importance to implement projects and strategies set in place for economic growth. Generally, the government depends heavily on tax source of revenue than on other sources. For example, on the financial year 2015/16, Tanzania government expected to raise 22.5 Trillion
Tanzanian shillings, of which 12.36 Trillion were to come from tax collection, this is equivalent to 55 percent of total expected revenue [7].

The table below shows the share of VAT on total revenue collected from tax sources in Tanzania. Apart from VAT other tax sources include; PAYE, corporate tax, individual, other income taxes, domestic excise duties, import duty and excise duties on imports.

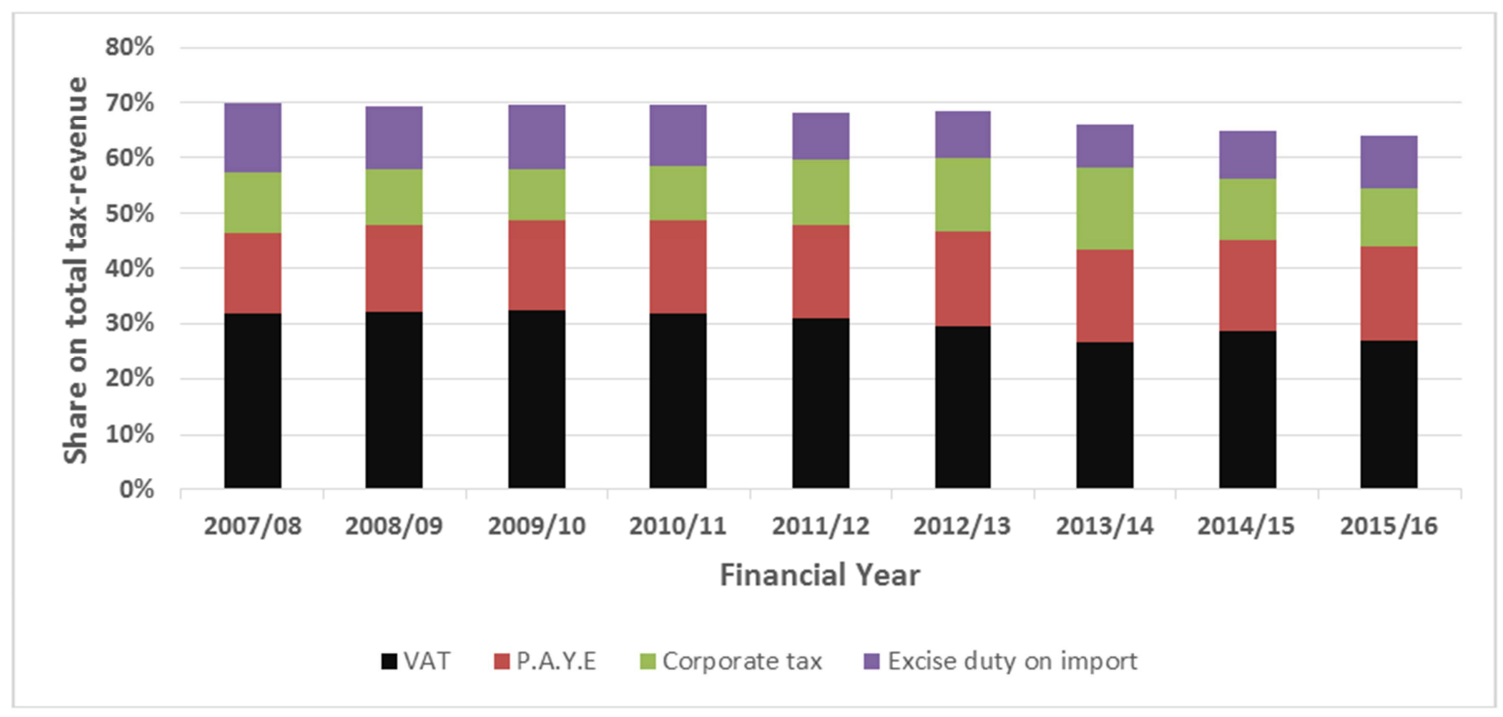

Figure 1. Share of Value-Added Tax on total tax revenue in Tanzania. Source: Tanzania Revenue Authority.

From the figure 1 above, amongst the four major tax sources that is P.A.Y.E (tax deduction on employee's income), Corporate tax, and Excise duty on import, annual share VAT on total tax revenue has been more than 25 percent, making it to be the largest tax revenue source.

\subsection{Problem Statement}

The major issue on tax collection has been compliance or non-compliance. Studies have been made on understanding the phenomenon from different perspectives, economics [810], social norms [11-12] and ethical behaviour [13], and due to complexity of compliance behaviour among entities, researchers are suggesting the combination of approaches [14]. The posed question has been how to tackle the noncompliance problem at minimal cost and without affecting efficiency operations of entities, but ensuring maximization of tax revenue collections.

Collection of tax that imposed on consumption of goods and services like VAT always involves three parties; the payee who is the bearer of tax burden, on middle part is a trader who is responsible in tax collection on behalf of the tax authority, and the final part is tax administration which oversees the whole tax system. Thus, in a course of increasing efficiency in managing tax collection, negligence of any of these parties is unacceptable.

According to [15], tax administration has mandatory authority to oversee tax collection, this including setting best modality in place for easy tax compliance, thus TRA as tax administration in Tanzania opted for Electronic Fiscal Devices. The second part which is VAT registered traders have responsibility which is governed by law to pay rightful amount of tax at required time period. Observations on many tax administrations is, their focus is normally made upon second part. All efforts are directed toward finding the best method that will enhance traders' compliance, that is for them to be able to pay rightfully amount of tax and at required time, while ignoring final consumer's part. However, given significance of all three parties on tax charged on goods and services, it is necessary customers to be taken on board [16-17].

For that reason, government, through its tax authority has a crucial role to play in encouraging high compliance level not only among traders (the middle part), but also among final consumers (bearer of tax burden) through; trust and fairness $[1,18,19]$, openness on usage of tax revenue towards provision of public goods and services [20], and quality of its administration [1].

In a course of improve tax administration, various tax authorities embark on technological solutions such as the use of electronic fiscal devices (EFDs) like; electronic cash register (ECRs), electronic signature devices (ESDs) and electronic fiscal printer (EFP) in combating non-compliance problem. However, it is cautioned that embracing these fiscal devices alone cannot guarantee tax compliance, because compliance behaviour can hardly be explained by a single factor, thus opting for EFDs should go parallel with other 
compliance improvement strategies to enhance revenue collection and combat non-compliance of tax payers [15, 21].

For the study case, Tanzania Revenue Authority (TRA) ${ }^{1}$ which is the governmental entity responsible for administering various taxes of Central Government, adopted Electronic Fiscal Devices (EFDs) ${ }^{2}$ in 2010 for VAT registered traders, this was phase one, while second phase started in 2013 for non-VAT registered traders ${ }^{3}$.

Basing on TRA, these devices are preferred because of having in-built fiscal memory that cannot be erased, transmission of tax information direct to TRA, and irreversible date mechanism and save configured data and records on permanent fiscal memory automatically. With these preferences, one can conclude that, adopted of devices were based on combating non-compliance.

However, situation on grounds show that, since the introduction of EFDs in Tanzania, a number of issues have been raising; first, boycotts of business operators, the VAT registered business firms have been resisting the usage of device in running their businesses, because device is seemingly expensive. Second issue being, despite some few business operators who decided to abide the "The Value Added Tax (Electronic Fiscal Device) Regulation, 2010”, only few have been issuing sales receipt by using EFDs. Signifying potential loss of revenue either way, because a day or two of traders' boycotts results to potential loss of revenue from business transactions which could not take place, and tax loss on unreported sales [22], [23].

As it argued that, most tax administrations work on treating non-compliance at firm-level rather than at finalconsumer level [16]. Similar efforts are shown by TRA by investing much on educating business traders on importance of integrating the use of EFDs on their business activities, while less has been lightened or directed toward imparting awareness to customers on importance of asking for EFD receipts whenever they made transactions.

The burden of VAT falls on final consumers; traders are in this part play crucial role on assisting tax administration on VAT collection. Thus, integrating consumer's equation in compliance strategies is expected to improve government revenue from tax collection [17].

\subsection{Research Hypotheses}

$\mathrm{H} 1$; There is positive relationship between attitude toward the act of asking for sales receipt when transaction is made and behavioral intention to do so.

$\mathrm{H} 2$; There is positive relationship between subjective norms and behavioral intention of asking for sales receipt when transaction is made.

H3; There is positive relationship between perceived behavioral control on asking for sales receipt when

1 Note that throughout the document, TRA will stand for Tanzania Revenue Authority, and

2 EFD will stand for Electronic Fiscal Device

3 http://www.tra.go.tz/index.php/e-fiscal-devices-efd (Accessed 13, July 2016; 18:02) transaction is made and behavioral intention to do so.

$\mathrm{H} 4$; There is positive relationship between behavioral belief of asking for sales receipt and attitude toward the act to do so.

H5; There is positive relationship between normative belief of asking for sales receipt and subjective norms.

H6; There is positive relationship between control belief of asking for sales receipt and perceived behavioral control.

\section{Methodology}

\subsection{Theory of Planned Behaviour}

With intention to uncover consumers' behaviour on receipt asking behaviour, this study adopt the theory of planned behavior which suggests that "behavior in question depends on one's intention to perform the behavior. Intention is determined by an individual's attitude (beliefs and values about the outcome of the behavior) and subjective norms (beliefs about what other people think the person should do or general social pressure). Behavior is also determined by an individual's perceived behavioral control, defined as an individual's perceptions of their ability or feelings of selfefficacy to perform behavior" [24].

The success of the planned behaviour model in explaining health psychology and other related behaviour, is of great value to understand consumer's behaviour in case of asking for sales receipt.

Reference [26] applied the theory in predicting the intention of Iranian students' in buying organic food, suggesting that is usefully to consider the theory for it has been used to understand range of consumer's intention and behaviour. In their study it was observed that the students' attitude was the main predictor of their intention to purchase organic foods while both perceived behavioral control and subjective norms were not significant predictors of intention [26].

Reference [27] when investigating consumers' intention to visit green hotels by application of extended theory of planned behaviour, indicate that "show that the consumer's attitude toward green hotels, subjective norms, and perceived behavioral control (i.e., the antecedents of the TPB model) indeed exert positive influences on the consumer's intention to visit green hotels" [27].

Apart from consumer related researches, the theory has been applied in various fields. Reference [28] investigated factors influencing business tax payers' decision on whether to report income and deductions correctly in their 2011 income tax return, by employing the Theory of Planned Behaviour, to see if it can reliably predict taxpayers' intention of fulfilling tax obligations. Study results showed that compliance behaviour cannot always be predicted by intention to comply, this is because majority of taxpayers who wanted to comply, failed. Thus the study suggested the incorporation of additional factors such as awareness of rules to predict compliance [28].

Reference [29] applied the Theory of Planned Behaviour 
on study of online course adoption in Public relation education. The findings show; all of the main predictor variables (Subjective Norms, Attitude toward the Act and Perceived Behavioral Control) were statistically significant at varying degrees in predicting intent to teach public relations online, and subjective norms was strongest predictor of intention [29].

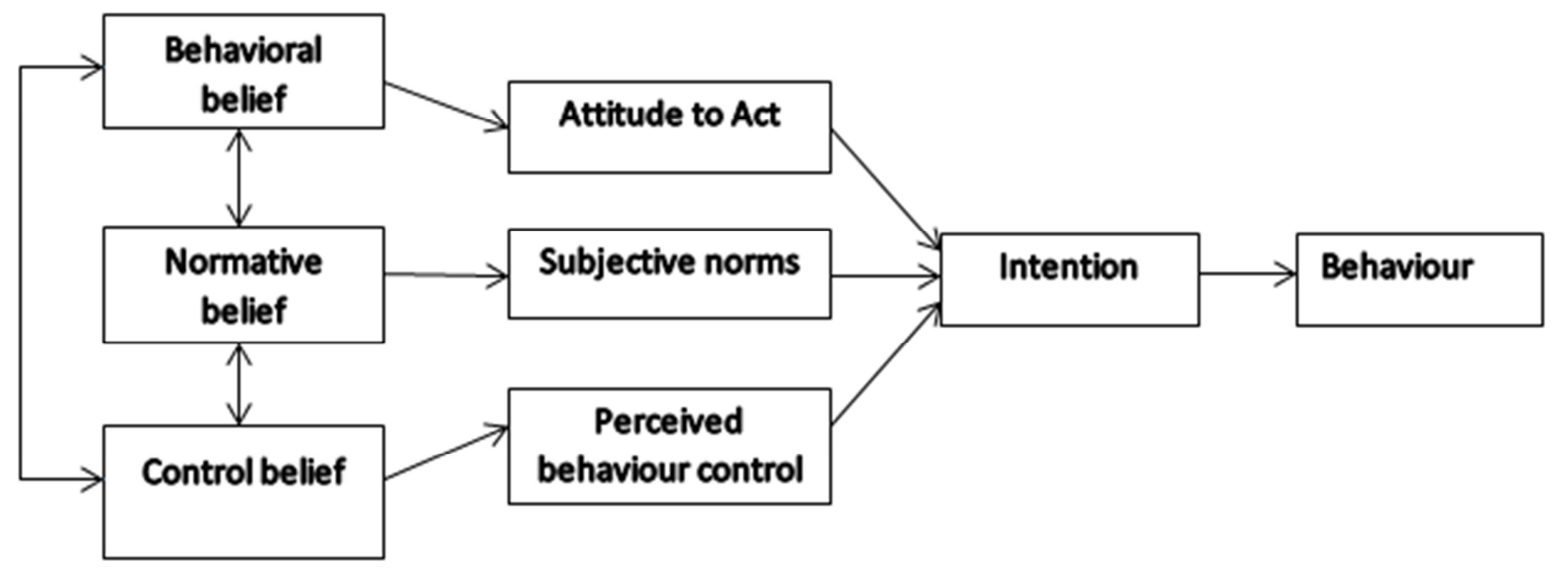

Figure 2. Model of Theory of Planned behaviour; Ajzen, (2015).

A study for consumer acceptance of online video and television service [30] supported applicability of the theory on are regarding acceptance, and revealed that perceived behavioral control was the highest contributor to predicting intention to use online video services [30].

\subsection{Method}

The study was conducted at Dodoma municipality, the capital of the country which accommodates different type of business activities from manufacturing, wholesaling and retailing businesses. The study sample containing 118 respondents, computed through Cochran's sample size formula by applying seven-point of Likert scale questions anchored by $1=$ very important and $7=$ unimportant, and alpha level of 0.05. The data were collected in August 2016 through questionnaire that was modified following pilot study of face to face interview with 40 random selected individuals and one focus group discussion of 15 candidates. All respondents consented to participate in study with assurance of anonymity and confidentiality.

\subsection{Reliability Test}

Prior model testing, the study undertook a reliability test, since in using different Likert scale questions in measuring one variable, one needs to check for internal consistency associated with scores that can be derived from the scale; this is relevant in crosschecking the validity of scale scores. Reliability test is done using Cronbach's Alpha test which is the most acceptable method for assessing reliability of scale, whereby cut-off point of 0.7 is said to be suitable correlation level among statements [26, 27, 29].

Table 1. Reliability results.

\begin{tabular}{|c|c|c|c|}
\hline Variable & 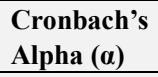 & $\begin{array}{l}\text { Number of } \\
\text { statements }\end{array}$ & Statements \\
\hline Intention & 0.716 & 3 & $\begin{array}{l}\text { I intend to request a sales receipt after a transaction. } \\
\text { I have decided to request a sales receipt after transaction } \\
\text { I am determined to request a sales receipt after transaction }\end{array}$ \\
\hline Attitude & 0.837 & 9 & $\begin{array}{l}\text { For me to request a sales receipt after transaction is made will be Good } \\
\text { For me to request a sales receipt after transaction is made will be Desirable } \\
\text { For me to request a sales receipt after transaction is made will be Easy } \\
\text { For me to request a sales receipt after transaction is made will be Useful } \\
\text { For me to request a sales receipt after transaction is made will be Important } \\
\text { For me to request a sales receipt after transaction is made will be Valuable } \\
\text { For me to request a sales receipt after transaction is made will be Beneficial } \\
\text { For me to request a sales receipt after transaction is made will be Provident } \\
\text { For me to request a sales receipt after transaction is made will be Prudent }\end{array}$ \\
\hline $\begin{array}{l}\text { Subjective } \\
\text { Norms }\end{array}$ & 0.74 & 3 & $\begin{array}{l}\text { When it comes to the situation of requesting a sales receipt, how much do you want to do what your } \\
\text { friends/peer thinks you should do } \\
\text { When it comes to the situation of requesting a sales receipt, how much do you want to do what tax } \\
\text { law or government or TRA think you should do }\end{array}$ \\
\hline $\begin{array}{l}\text { Perceived } \\
\text { behaviour }\end{array}$ & 0.772 & 2 & $\begin{array}{l}\text { For me to request a sales receipt after transaction, it will be Easy } \\
\text { It is mostly up to me when it comes to request sales receipt after transaction }\end{array}$ \\
\hline $\begin{array}{l}\text { Behavioral } \\
\text { Belief }\end{array}$ & 0.784 & 6 & $\begin{array}{l}\text { Requesting a receipt after transaction is made will help me to be secured with my commodity } \\
\text { Being secured with my commodity is important }\end{array}$ \\
\hline
\end{tabular}




\begin{tabular}{llll}
\hline Variable & $\begin{array}{l}\text { Cronbach's } \\
\text { Alpha }(\boldsymbol{\alpha})\end{array}$ & $\begin{array}{l}\text { Number of } \\
\text { statements }\end{array}$ & Statements \\
\hline & & $\begin{array}{l}\text { Requesting a receipt after transaction is made is what a responsible citizen does } \\
\text { Being a responsible citizen is very important } \\
\text { Requesting a receipt after transaction is made will help me keep records of my expenditure } \\
\text { Keeping records of my spending is important } \\
\text { My president thinks that (I should) request sales receipt after transaction }\end{array}$ \\
$\begin{array}{l}\text { Normative } \\
\text { belief }\end{array}$ & 0.805 & 3 & $\begin{array}{l}\text { My Parents think that (I should) request sales receipt after transaction } \\
\text { Most of my friends think that (I should) request sales receipt after transaction } \\
\text { How often does negotiating price discourage you from asking for/writing a sales receipt } \\
\text { Purchasing warranted product will make easier to request a receipt } \\
\text { If a seller is trustworthy, I expect to request for sales receipt } \\
\text { Purchase made to trustworthy seller will make easier to request a receipt }\end{array}$ \\
\hline Control Belief & 0.759 & 4 &
\end{tabular}

\section{Results}

\subsection{Descriptive Analysis}

The 118 respondents in the study had age range between 18 and 55 , with mean age of 28.9 years $(\mathrm{SD}=7.45)$, whereby 67 participants (equivalent to $56.8 \%$ ) were male with average daily expenditure of 10,380Tshs (4.7 USD), and 51 participants (equivalent to $43.2 \%$ ) were female with average daily expenditure of 8,098 Tshs (3.7 USD) ${ }^{4}$.

\subsection{Drivers of Intention to Ask for Sales Receipt}

The analysis was made using Amos v18 on original TPB model, whereby 33 percent (figure 3) variation on consumer intention to ask for sales receipts can be explained by variables included in the model. Two of the explanatory variables that is Attitude $(\beta=0.484, p<0.001)$ and Subjective norms $(\beta=0.334, p<0.001)$ have significant positive effect on Intention to ask for sales receipt. In line with that, Behaviour belief $(\beta=0.435, p<0.001)$ significantly influences customer's attitude positively, and so is the effect of Normative belief $(\beta=0.766, p<0.001)$ on Subjective norms, and Control belief positively influence Perceived Behaviour Control $(\beta=0.542$, $\mathrm{p}<0.001)$. However, there was no effect of Perceive behaviour control $(\beta=-0.131, \quad \mathrm{p}<0.102)$ on customer's intention to ask for sales receipt (table 2).

Table 2. Summary of Model's Estimates.

\begin{tabular}{lllll}
\hline \multicolumn{3}{l}{ Relationship among variables } & Estimates & Significance \\
\hline First part & & & & \\
Intention & $<---$ & Attitude & .484 & $* * *$ \\
Intention & $<---$ & Subjective Norms & .334 & $* * *$ \\
Intention & $<---$ & Perceived Behaviour & -.131 & 0.102 \\
$\begin{array}{l}\text { Second part } \\
\text { Attitude }\end{array}$ & & & & \\
Subjective & $<---$ & Behaviour Belief & .435 & $* * *$ \\
$\begin{array}{l}\text { Norms } \\
\text { Perceived }\end{array}$ & $<---$ & Normative Belief & .766 & $* * *$ \\
Behaviour & $<---$ & Control Belief & .542 & $* * *$ \\
\hline
\end{tabular}

$* * *$ significant at $1 \%$

Based on these results, the null hypothesis is rejected (P-

4 Conversion of Tshs to US dollar is based on average exchange rate of August 2016

(http://www.bot.go.tz/FinancialMarkets/IFEMsummaries/IFEMsummaries.asp) value $<0.000$ ) in favour of the first two hypotheses set by the study, that is $\mathrm{H} 1$; There is positive relationship between attitude toward the act of asking for sales receipt when transaction is made and behavioral intention to do so, and $\mathrm{H} 2$; There is positive relationship between subjective norms and behavioral intention of asking for sales receipt when transaction is made. However, we fail to reject null hypothesis in favour of $\mathrm{H} 3$; There is positive relationship between perceived behavioral control on asking for sales receipt when transaction is made and behavioral intention to do so, since P-value $>0.05$.

Similarly, these findings support fourth and fifth hypotheses of the study that is H4; There is positive relationship between behavioral belief of asking for sales receipt and attitude toward the act to do so, $\mathrm{H} 5$; There is positive relationship between normative belief of asking for sales receipt and subjective norms, respectively. And for sixth hypothesis, study results imply there is no relationship between control belief of asking for sales receipt and Perceived Behavioral Control to do so.

\section{Discussion and Implication}

Significance of attitude on behaviour intention implies that, most of the customers acknowlege goodness, desirability or importance of asking for sales receipt, but as it has been cautioned $[31,32]$ if customers do not see the direct benefit of tax collected by their act of asking of receipts, then this positive attitude might not guarantee the willingnes to implement the behaviour. This is verified by findings which shows that 87.3 percent of respondents agreed to the fact that, asking for receipt will enhance government revenue, but fewer customers $(68.7 \%)$ see enhancing government revenue to be of importance. This carry implication to government on tax collection performance, when bearers of tax burden sees the benefit of their actions, then it is likely for them to act as wishtle browers on tax collection exercise [16].

Similarly, being responsible citizen, having receipt as way of keeping record on expenditure and security on ownership of commodity which define behaviour belief, positively affect the attitude of asking for receipts. Thus promoting virtue of record keeping, while returning to the public what they have assisted in tax collection as third-party tax enforcers motivating them of being responsible citizens will eventually affect the behavioural intention. 


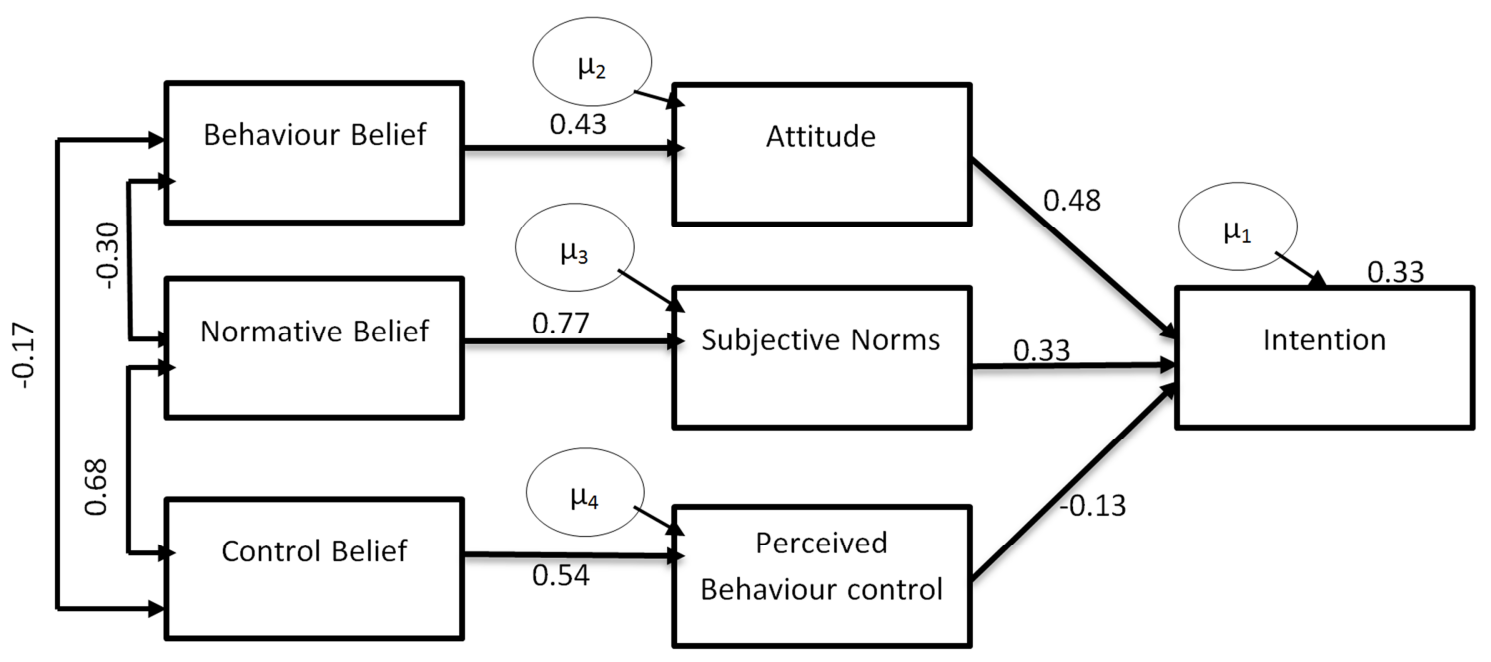

Figure 3. TPB model standardized estimates.

According to financial act, a failure to demand or report a denial of issuance of fiscal receipt or fiscal invoice upon payment for goods or services is punishable by law [33]. However from study conducted in Italy and Belgium showed that, penalizing final consumers bared no fruits, so were the monetary incentives equivalent to percentage of tax that was to be collected [32]. Thus, emphasis should be on promoting budgetary transparency and on good relationship between revenue authority and stakeholders involved in transaction, rather than promoting material incentives to third-part tax enforcers [34, 35].

Relatives and friends have significant effect of individual behaviour of asking for receipt, this imply that if the community positively agree with the culture of asking for sales receipts, then indivudual behaviour is likely to change in direction of social norms, and thus reducing moral and ethical cost when customer act as a third-party tax enforcer [36].

\section{Conclusion}

Study investigates underlying factors determining behaviour of consumer as third-party tax enforcer through asking for sales receipts after transaction. Analysis made on 118 consumers, indicates that, attitude and subjective norms exert positive effect on intention to ask for sales receipt, hence determining the behaviour of customer in asking for sales recipt. Meanwhile; perceive behaviour control shows no effect on customer's intention to ask for sales receipt. Positive effect of consumer's attitude on intention of asking for sales receipt comes from customer's acknowlege on goodness, desirability, and importance of asking for sales receipt, which is argued to have implication on effeciency of tax collection exercise. Morover, subjective norms which focus on social pressure a customer faces in either perfoming or not perfoming the targeted behaviour, indicates that; relatives and friends positively influence individual intention so is the behaviour of asking for receipt. Therefore, existance of habit of asking for sales receipt among community members reduces moral and ethical cost of acting as a thirdparty tax enforcer thus increases the likelihood of individual in asking for sales recipt after transactions.

\section{Recommendations}

Reference [15] pointed out that, to most small and medium business interprise which are dominated by cash transaction, information from third-party is of great value in cross checking tax declaration data, therefore, efforts of tax administration should be directed more toward winning consumers' support rather than using more force towards traders on adoption and use of EFDs machines [15].

"The introduction of EFDs has not been associated with noticeable increases in VAT revenue as a percentage of GDP" [15]. Henceforth collection of VAT should not end up with only introduction and use of EFDs, rather it should go parallel with other strategies aiming at improving tax collection exercise such as; equipping tax administration with qualified, non-corrupted and well paid staff, updated ICT equipment, sufficient and sustained funding and with good relationship among stakeholders involved in tax system [15, 35].

Further studies should be conducted on; understanding and determining incentive to consumers on sale receipt requesting, how is EFDs integrated at lowest levels of business transaction when paying for consumables at retail stores, and on how revenue authority keep up with technological change whereby tax evaders continues to find more sophisticated ways of evading taxes.

\section{References}

[1] OECD, Tax and Development: Aid Modalities for Strengthening Tax System. OECD Publishing, 2013.

[2] UNESCO, "Increasing tax revenues to bridge Education financing gap," Educ. All Glob. Monit. Rep., no. March 2014, 2014. 
[3] K. Pomerleau, "Sources of government revenue in the OECD, 2015," Tax Found., no. 465, pp. 1-8, 2015.

[4] L. Ebrill, M. Keen, J.-P. Bodin, and V. Summers, "The Allure of the Value-Added Tax," Finance Dev., vol. 39, no. 2, 2002.

[5] J. Aizenman and Y. Jinjarak, "The collection efficiency of the value added tax: theory and international evidence by Joshua Aizenman and Yothin Jinjarak," J. Int. Trade Econ. Dev, vol. 17, no. 3, pp. 391-410, 2005.

[6] OECD, Revenue Statistics 2016. OECD Publishing, 2016.

[7] Ministry of Finance, "Government Budget for Financial year 2015/16,” Dar es Salaam, 2015.

[8] A. Piolatto, "Itemised Deductions: A Device to Reduce Tax Evasion," Ger. Econ. Rev., vol. 16, no. 4, pp. 422-438, 2014.

[9] L. Goerke and M. Runkel, "Tax Evasion and Competion," Scottish J. Polit. Econ., vol. 58, no. 5, 2011.

[10] R. Bayer and F. Cowell, "Tax compliance and firms' strategic interdependence," J. Public Econ., vol. 93, pp. 1131-1143, 2009.

[11] D. D. Bobek, A. M. Hageman, and C. F. Kelliher, "Analyzing the Role of Social Norms in Tax Compliance Behavior," pp. 451-468, 2013

[12] J. Cullis, P. Jones, and A. Savoia, "Social norms and tax compliance : Framing the decision to pay tax," J. Socio. Econ., vol. 41, no. 2, pp. 159-168, 2012.

[13] J. Alm and B. Torgler, "Do Ethics Matter? Tax Compliance and Morality," J. Bus. Ethics, vol. 101, no. 4, pp. 635-651, 2011.

[14] J. Alm, E. Kirchler, and S. Muehlbacher, "Combining Psychology and Economics in the Analysis of Compliance: From Enforcement," Econ. Anal. Policy, vol. 42, no. 2, pp. 133-151, 2012.

[15] P. Casey and P. Castro, "Electronic Fiscal Devices ( EFDs ) An Empirical Study of their Impact on Taxpayer Compliance and Administrative Efficiency," WP/15/73, 2015.

[16] J. Naritomi, "Consumers as Tax Auditors," Work. Pap., 2013.

[17] D. Gamage, A. B. Thimmesch, and D. Shanske, "The Case for Consumer-Based Use Tax Enforcement," Maurer Fac. 2640, 2017.

[18] S. Muehlbacher and E. Kirchler, "Tax Compliance by Trust and Power of Authorities," Int. Econ. J., vol. 24, no. 4, pp. 607-610, 2010 .

[19] J. Andreoni, B. Erard, and J. Feinstein, “Tax Compliance," $J$. Econ. Lit., vol. 36, no. 2, pp. 818-860, 1998.

[20] S. Leder, L. Mannetti, E. Hölzl, and E. Kirchler, "Regulatory fit effects on perceived fiscal exchange and tax compliance," J. Socio. Econ., vol. 39, pp. 271-277, 2010.

[21] N. Saad, "Tax Non-Compliance Behaviour: Taxpayers View,"
Procedia - Soc. Behav. Sci., vol. 65, no. ICIBSoS, pp. 344 351, 2012.

[22] H. Ngowi, "ECONOMICS MADE SIMPLE : Electronic fiscal device saga in Tanzania: Understanding issues," The Citizen, Dar es Salaam, 15-Feb-2014.

[23] M. Suleyman, "Stores reopen after four days of boycott," The Citizen, Mwanza, 03-Feb-2014.

[24] World Bank, "Theories of Behavior Change," Washighton DC, 2010.

[25] I. Ajzen, "Consumer attitudes and behavior: the theory of planned behavior applied to food consumption decisions," Rivivista di Econ. Agrar., vol. 2, no. AnnoLXX, pp. 121-138, 2015.

[26] M. Yazdanpanah and M. Forouzani, "Application of the Theory of Planned Behaviour to predict Iranian students' intention to purchase organic food," J. Clean. Prod., vol. 107, pp. 342-352, 2015.

[27] M. Chen and P. Tung, "International Journal of Hospitality Management Developing an extended Theory of Planned Behavior model to predict consumers ' intention to visit green hotels," Int. J. Hosp. Manag., vol. 36, pp. 221-230, 2014.

[28] J. Langham, N. Paulsen, and C. E. J. Härtel, "Improving tax compliance strategies: can the theory of planned behavior predict business compliance?," eJournal Tax Res., vol. 10, no. 2, pp. 364-402, 2012.

[29] A. Knabe, "Applying Ajzen's Theory of Planned Behavior to a Study of Online Course Adoption in Public Relations Education," Fac. Grad. Sch., p. 256, 2009.

[30] Y. Truong, "An Evaluation of the Theory of Planned Behaviour in Consumer Acceptance of Online Video and Television Services," Electron. J. Inf. Syst. Eval., vol. 12, no. 2, pp. 177-186, 2009.

[31] M. Fabbri and S. Hemels, “" Do you want a receipt?' Combating VAT and RST evasion with lottery tickets," no. October, pp. 1-21, 2012.

[32] M. Fabbri and D. C. Wilks, "Tax Lotteries: the Crowding-out of Tax Morale and Long-run Welfare Effects," Rotterdam, 2016.

[33] Ministry of Finance, The Financial Act, 2016. United Republic of Tanzania: Ministry of Finance, 2016.

[34] B. M. Djawadi and R. Fahr, "The Impact of Tax Knowledge and Budget Spending Influence on Tax Compliance," J. Econ. Lit., no. 7255, pp. 0-33, 2013.

[35] M. Keen, J. Toro, K. Baer, V. Perry, J. Norregaard, J. Ueda, J. Brondolo, D. Cleary, E. Hutton, O. Luca, E. Rojas, M. Thackray, and P. Wingender, "Current Challenges in Revenue Mobilization: Improving Tax Compliance," Staff Rep., no. April, pp. 1-79, 2015.

[36] R. W. McGee, The Ethics of Tax Evasion. New York: Springer Science+Business Media, 2012. 